\title{
Use of propolis in difficult to heal diabetic wounds. Short review
}

\begin{abstract}
According to WHO, about 347 million of people worldwide suffer from diabetes. Diabetes has complex etiology, and the consequences of this illness are seen in the morphological changes of many tissues and organs i.e. neuropathy leading to the risk of diabetic foot. Due to the diabetic condition, injuries to blood vessels in diabetic foot can be classified as chronic. This is because such wounds remain unresponsive to treatment for months or even years. There are many therapeutic methods employed in treating such injuries. These involve the use of silver, iodine or multi-antibiotic preparations, but treatment is expensive and cumbersome for patients. In the natural environment, however, there are many anti-inflammatory preparations, among them propolis which was the subject of our focus. Due to its anti-inflammatory, antimicrobial, and antioxidant properties, propolis is widely used in the treatment of colds, caries, rheumatic diseases, heart diseases and treatment of burns, wounds and frostbites. Nume -rous studies also indicate the beneficial effects of propolis on the difficult to heal diabetic wounds in which the use of propolis can significantly accelerate the healing process. The treatment utilizing propolis is easy, inexpensive and does not seem to cause any side effects, therefore costs can be reduced to minimum. The few studies conducted in diabetic patients confirm the results obtained in laboratory animals.
\end{abstract}

Keywords: diabetic wounds, propolis, wounds healing process.

DOI: $10.1515 /$ pjph-2017-0037

\section{INTRODUCTION}

According to WHO, about 347 million of people worldwide suffer from diabetes. Diabetes is a metabolic disease with complex etiology. As a result of the destruction of pancreatic beta cells or their development of resistance to insulin, chronic hyperglycemia and metabolic disorders of carbohydrates, fats and proteins occur. The end results are seen in the morphological and functional changes of many tissues and organs, including retinopathy, nephropathy and neuropathy [1]. The main consequence of neuropathy is the risk of diabetic foot. Herein, damage to the sensory nerves leads to reduction of pain within the wound so that patients are often unaware of the injury. Injuries are, hence, untreated and become easy gateways for bacterial infiltration $[2,3]$. The resulting wounds are classified as chronic ones and can remain unresponsive for months or even years. There are currently many therapeutic methods employed involving the use of silver, iodine or multi-antibiotic preparations [4]. However, such treatment is expensive and cumbersome for patients [3,5]. There are, nevertheless, many anti-inflammatory, antibacterial preparations in the natural environment and propolis is one of them. This was the subject of our focus.

The name 'propolis' is derived from the Greek word 'pro' - in front, and 'polis' - city, meaning 'in front of the city'. This label reflects its valuable protecting role in public and private health-care [6-8]. To produce propolis, bees collect materials from the different parts of flowering plants e.g. lipophilic materials from leaves and buds, mucilages, gums, resins and lattices $[7,9,10]$. The obtained material is then mixed with secretions from bee's mandibular and hypopharyngeal glands $[10,11]$. Propolis was used in the ancient times in mummification rituals and in traditional health care. Nowadays, it is commonly employed in the world food industry, in cosmetology [12] and in traditional/conventional medicine. Recently, propolis has been used to treat wounds [13-15] and burns [16-18], to prevent anti-cariogenic activity [19], to eliminate endodontic dental infection [20], to treat oral and respiratory system infections, as well as mucositis [21,22] and stomach ulcer [10]. Bankova et al. [10] also give several examples of new fields in which propolis can be used.

This review seeks to investigate the functional properties of propolis and bee-derived products in difficult to heal diabetic wounds under experimental conditions of diabetes in animals and in humans.

\section{The use of propolis in diabetic wounds}

In the study of McLennan et al. [14], the authors investigated, on the basis of the diabetic rat model, the influence of the application of propolis on epithelial closure, wound morphology, cellular infiltrate and blood vessel density. In the group of diabetic animals with wounds treated with saline, the wound closure and re-epithelialization were significantly decreased in comparison to a non-diabetic control group. With the use of propolis in diabetic animals, however, wound closure was improved, while in comparison, no effect was seen in a similar indicator within the control group. It was also observed that 
the use of propolis for diabetic wounds decreases the amount of neutrophils and regulates the inflow of macrophages to tissue. Still, on the $6^{\text {th }}$ and $12^{\text {th }}$ day of the experiment, diabetes and use of propolis did not have any effect on the number of blood vessels and their branching [14]. The study of Hozzein et al. [23], on the diabetic mouse model showed that the use of propolis significantly enhanced both the closure of wound and the production of collagen, in comparison to untreated animals. Moreover, application of propolis decreased the level of MMP9 (matrix metalloproteinase 9) and TGF- $\beta 1$ (transforming growth factor $\beta 1$ ), both of which are important regulators of wound healing and of inflammatory cytokines (IL-1 $\beta$, IL-6, and TNF- $\alpha$ ) in wounds. In conclusion, the application of propolis in the diabetic mouse model was seen to improve the healing and closure of wounds.

Similar work was carried out by Rashidi et al. [24] in experimental diabetic rats, wherein they used a mixture of honey, royal jelly and olive oil-propolis extract on wounds. The results confirm the aforementioned McLennan's et al. [14] and Hozzein's et al. [23] studies, wherein the application of such mixture cream significantly increased the healing and repair of wounds in diabetic and non-diabetic rats.

In the Ahmed's et al. study [25], the authors investigated in diabetic rats the rate of burn wound repairing processes, as well as attendant bacterial colony counts (BCC) after treatment with propolis, dermazin, and propolis-dermazin. Herein, they noted that in the rats treated with combined propolis-dermazin, bacterial colony counts were reduced in all days of the study, in comparison to all the other studied groups. Furthermore, the BCC were lower in the propolis-treated group than in that of dermazin on the 15, 20 and 25 day counts. Interestingly, there were significant differences in BCC at different times between all groups $(\mathrm{P} \leq 0.05)$. To assess the rate of skin regeneration, the authors also measured burn surface area (BSA) on different days of experience. In the propolis-dermazin treatment, BSA were significantly reduced, in comparison to that of all the other groups. Moreover, the BSA on the $19^{\text {th }}$ and $24^{\text {th }}$ days of the study, with regard to the propolis-treated group, were lower than that in the dermazin group. In conclusion, the use of propolis or a combination of propolis-dermazin can effectively improve the healing process of burn injuries in experimental diabetic rats [25]. Similarly, in another experiment, the authors assessed the antibacterial activities and the healing effect of a carboxymethyl cellulose (CMC) hydrogel with honey on diabetic ulcers in mice. The obtained results show that CMC with honey has a positive effect on the bacterial colony count, and that the antibacterial properties of this compound increase with the higher honey concentration. What is more, in the control group, the wound surface areas were bigger than that seen in the hydrogel CMC group or the CMC with honey group. In conclusion, the obtained results show that CMC hydrogel with honey significantly improves the healing of wounds in the diabetic mouse model, and that it can be an effective therapeutic agent for ulcer wounds [26]. Another work evaluated the topical application of propolis, black seed and honey on the healing of oral mucosa of diabetes rabbits. The results showed that such treatment improves the re-epithelialization and remodelling of the dermis [27].

Lotfy et al. [28] analyzed the use of a topical application of honey, bee propolis and myrrh (MPH) on an infected and deeply abscessed wound in a diabetic patient. The best results were noted after the application of a paste with $800 \mathrm{mg}$ of bee propolis and $50 \mathrm{~g}$ of myrrh, mixed together with honey.
The wound healed cleanly without any pus and cellular exudate, and the patient was able to return to work after 4 weeks of therapy.

At the Royal Prince Alfred Hospital, in Sydney, Australia, another study analysed the effect of single topical application of propolis in patients with type 1 and type 2 diabetes. Herein, the ulcer area in the 1 st week was reduced in the propolis group to an extent of $41 \%$, compared to $16 \%$ in the control group $(\mathrm{P}<0.001)$; in the $3^{\text {rd }}$ week the figures were $63 \%$ vs. $44 \%$, respectively $(\mathrm{p}<0.05)$. What is more, the number of patients with complete healing of their ulcers in the $4^{\text {th }}, 5^{\text {th }}$ and $7^{\text {th }}$ weeks was greater in the propolis treated group than in the control group. There was also decrease in the number of bacterial colonies in the wound area in the group treated with propolis. In addition, the active form of MMP-9 was more rapidly reduced in patients treated with propolis than that in the control group $(\mathrm{p}<0.05)$. The obtained results, therefore, confirm that the use of propolis in patients with diabetes significantly improves the treatment of ulcerative wounds and does not cause any side effects [29].

In 2015, Ragab et al. [30] investigated the influence of a propolis dressing on the healing of septic diabetic foot ulcer patients (DFUs). At the end of the study, it was found that propolis significantly decreased ulcer area $(\mathrm{P}=0.01)$ and depth $(\mathrm{P}=0.02)$, compared to that of a control group. Moreover, $76.6 \%$ of patients treated with propolis had complete ulcer healing, while $23.3 \%$ had partial healing. In the control group, no patients had complete ulcer healing, while $66.66 \%$ of them had partial ulcer healing, and 33.3\% complained of a lack of healing. This study conducted on patients confirms that propolis accelerates wound healing. A similar study was conducted by Othman et al. [31] on diabetic foot ulcers patients in the Jabir Abu Eliz Diabetic Centre - Khartoum. Herein, the mean healing period in a group of patients treated with propolis and honey was significantly shorter (11.55 weeks) than in a group using tap water irrigation alone (15 weeks). Moreover, in the study group there was no limb amputation, while in the control group there were three. To sum up, the results indicate that the use of propolis and bee honey improve the healing and reduce the rate of toe amputation in diabetic foot ulcer patients [31].

\section{CONCLUSION}

The results of the presented research indicate the beneficial effects of propolis treatment alone or propolis with other active substances on difficult to heal diabetic wounds. This effect is probably associated with its anti-inflammatory, antioxidant and antimicrobial activities. Propolis or a mixture of various bee substances can, therefore, significantly accelerate the healing process of difficult to heal diabetic wounds in different animal species. The use of propolis is easy, inexpensive, and it does not seem to cause any side effects, hence, the cost of treatment can be reduced to minimum. The few stu dies conducted in diabetic patients confirm the results obtained in laboratory animals. 


\section{REFERENCES}

1. Drągowski P, Czyżewska U, Cekała E, et al. Cukrzyca jako problem społeczny i ekonomiczny. Pol Prz Nauk Zdr. 2014;2(39):163-6.

2. Adeghate J, Nurulain S, Tekes K, et al. Novel biological therapies for the treatment of diabetic foot ulcers. Expert Opinion Biol Ther. 2017;1:1-9. [http://dx.doi.org/10.1080/14712598.2017.1333596]

3. Robaczewska I, Filanowicz M, Cegła B. Pielęgniarskie działania oparte na stosowaniu specjalistycznych opatrunków ratujących stopę cukrzycową. Piel Pol. 2014;1(51):41-8.

4. Koblik T. Zespół stopy cukrzycowej. Trudno gojące się i przewlekłe rany istotny problem medyczny. Diabetol Prakt. 2007;8(1):22-7.

5. Viswanathan V. Role of molecular genetics in diabetic foot ulcer. Pol Arch Intern Med. 2017;127(5):310-1.

6. Bogdanov S. Propolis: composition, health, medicine: a review. Bee Product Science. 2014. [www.bee-hexagon.net] (accessed on 10 February 2017).

7. Miguel MG, Antunes MD. Is propolis safe as an alternative medicine? Journal of Pharmacy \& BioAllied Sciences. 2011;3(4):479-95. doi: 10.4103/0975-7406.90101.

8. Sforcin JM. Biological properties and therapeutic applications of propolis Phytother. Res. 2016;30(6):894-905. DOI: 10.1002/ptr.5605.

9. Bankova V, Popova M, Trusheva B. Propolis volatile compounds: chemical diversity and biological activity: a review. Chem Cen J. 2014;8:28. DOI: 10.1186/1752-153X-8-28.

10. Bankova V, Popova M, Trusheva B. New emerging fields of application of propolis. Maced J Chem Chem En 2016;35(1):1-11. [http://dx.doi. org/10.20450/mjcce.2016.864.]

11. Kurek-Górecka A, Rzepecka-Stojko A, Górecki M, et al. Structure and antioxidant activity of polyphenols derived from propolis. Molecules. 2014;19(1):78-101. doi:10.3390/molecules19010078.

12. Freires IA, de Alencar SM, Rosalen PL. A pharmacological perspective on the use of Brazilian Red Propolis and its isolated compounds against human diseases. Eur J Med Chem. 2016;110:267-79.

13. Berretta AA, Nascimento AP, Bueno PCP, et al. Propolis Standarized extract $(\mathrm{EPP}-\mathrm{AF} \AA)$, an innovative chemically and biologically reproducible pharmaceutical compound for treating wounds. Int J Biol Sci. 2012;8(4):512-21. doi: 10.7150/ijbs.3641.

14. McLennan SV, Bonner J, Milne S, et al. The anti-inflammatory agent Propolis improves wound healing in a rodent model of experimental diabetes. Wound Rep Reg. 2008;16:706-13.

15. Pillai SI, Palsamy P, Subramanian S, Kandaswamy M. Wound healing properties of Indian propolis studied on excision wound-induced rats. Pharm Biol. 2010;48(11):1198-206. doi:10.3109/13880200903578754.

16. Jastrzębska-Stojko Ż, Stojko R, Rzepecka-Stojko A, et al. Biological activity of propolis-honey balm in the treatment of experimentally -evoked burn wounds. Molecules. 2013;18(11):14397-413. doi:10.3390/ molecules181114397.
17. Olczyk P, Komosińska-Vassev K, Winsz-Szczotka K, et al. Propolis modulates vitronectin, laminin, and heparan sulfate/heparin expression during experimental burn healing. Zhejiang Univ-Sci B (Biomed \& Biotechnol). 2012;13(11):932-41.

18. Olczyk P, Komosinska-Vassev K, Winsz-Szczotka K, et al. Propolis induces chondroitin/dermatan sulphate and hyaluronic acid accumulation in the skin of burned wound. Evid-Based Compl Alt Med. 2013. ID 290675. http://dx.doi.org/10.1155/2013/290675.

19. Soares Machado B, Neves Pulcino T, Lima Silva A, et al. Propolis as an alternative in prevention and control of dental cavity. J Apither 2016;1(2):47-50. DOI:?10.5455/ja.20160726115117.

20. Agrawal V, Kapoor S, Agrawal I. Critical review on eliminating endodontic dental infections using herbal products. J Dietary Suppl. 2017;14(2):22940. DOI: 10.1080/19390211.2016.1207004.

21. Henatsch D, Wesseling F, Kross KW, Stokroos RJ. Honey and beehive products in otorhinolaryngology: a narrative review. Clin Otolaryngol. 2016;41(5):519-31. DOI: 10.1111/coa.12557.

22. Yumnam R, Nandan N, Kumar NC, et al. Effect of propolis in oral health. J-AIM. 2017;2(1):186-92. http://www.jaims.in/index.php/jaims/article/ view/195.

23. Hozzein WN, Badr G, Al Ghamdi AA, et al. Topical application of propolis enhances cutaneous wound healing by promoting TGF-beta/smad-mediated collagen production in a streptozotocin-induced type I diabetic mouse model. Cell Physiol Biochem. 2015;37:940-54. DOI: 10.1159/000430221.

24. Rashidi MK, Mirazi N, Hosseini A. Effect of topical mixture of honey, royal jelly and olive oil-propolis extract on skin wound healing in diabetic rats. Wound Med. 2016;12:6-9. http://dx.doi.org/10.1016/j.wndm.2015.12.001.

25. Ahmed ET, Abo-Salem OM, Osman A. The influence of egyptian propolis on induced burn wound healing in diabetic rats; Antibacterial Mechanism. Sci J Med Clin Trials. 2011. Article ID: 2011-2317.

26. Nho YC, Park JS, Lim YM. Preparation of hydrogel by radiation for the healing of diabetic ulcer. Radiat Physics Chem. 2014;94:176-80. http:// dx.doi.org/10.1016/j.radphyschem.2013.07.021.

27. Al-Gaban NMH, Ghani BA, Kadhim EF. Evaluation of topical application of propolis, black seeds and honey on oral mucosal healing in rabbits (histological and immunohistochemical study on TGF- $\beta 3$ ). Int J Sci Res. 2017;2319-7064. DOI:10.21275/ART20164558.

28. Lotfy M, Badra G, Burham W, Alenzi FQ. Combined use of honey, bee propolis and myrrh in healing a deep, infected wound in a patient with diabetes mellitus. Br J Biomed Scie. 2006;63(4):171-3.

29. Henshaw FR, Bolton T, Nube V, et al. Topical application of the bee hive protectant propolis is well tolerated and improves human diabetic foot ulcer healing in a prospective feasibility study. JDC . 2014;28:850-7. [http:// dx.doi.org/10.1016/j.jdiacomp.2014.07.012.]

30. Ragab AI, Mekkawy MM, El-Gamil A, Mohanny KM. Effect of propolis dressing technique on the healing of septic diabetic foot ulcers. J Nurs Health Sci. 2015:4(4):33-52. DOI: 10.9790/1959-04423352.

31. Othman AA, Balila RMH, Mahdi SEI, Ahmed ME. Healing potential of propolis and bee's honey on diabetic foot ulcers in Jabir Abu Eliz Diabetic Center-Khartoum. Sudan Med J. 2016;52(2):81-84.

\section{Corresponding author}

Dr Patrycja Chylińska-Wrzos

Medical University of Lublin

11 Radziwiłłowska St., 20-080 Lublin, Poland

E-mail: patrycja.wrzos@umlub.pl

tel: 814486158 